\title{
DYNAMICS OF HERBACEOUS VEGETATION IN CAATINGA MANIPULATED WITH GRAZING EXCLUSION UNDER PHOSPHATE FERTILIZATION ${ }^{1}$
}

\author{
PEDRO MOUZINHO DE OLIVEIRA NETO ${ }^{2 *}$, MÁRCIO VIEIRA DA CUNHA ${ }^{2}$, EVARISTO JORGE DE OLIVEIRA ${ }^{3}$, \\ MÉRCIA VIRGINIA FERREIRA DOS SANTOS ${ }^{2}$, JANETE GOMES DE MOURA ${ }^{2}$
}

\begin{abstract}
The semi-arid region accounts for about $70 \%$ of the surface area of the Brazilian northeast, and the most important forage resource is the Caatinga, covering approximately $54 \%$ of this region. However, about $40 \%$ of this vegetation is in secondary succession. The areas in the process of degradation range from low to severe intensity, and total more than 20 million hectares, reflecting the intense use of the land, such as the overgrazing. The objective of this study was to evaluate the influence of different doses of phosphorus $(0,50$ and $100 \mathrm{~kg} \mathrm{P}_{2} \mathrm{O}_{5} \mathrm{ha}^{-1}$ year $^{-1}$ ) on the dynamics of herbaceous vegetation at different times of the year, in a Caatinga area manipulated without grazing for four years. The experiment was conducted at the Serra TalhadaUFRPE Academic Unit during the years 2015 and 2016. We used a randomised block design with three blocks and four replicates per block. Phosphate fertilisation in grazing exclusion areas promoted an increase in forage mass of the enriched Caatinga herbaceous stratum at all evaluation times, especially in the dry season of 2016, which showed values above the average of $7950 \mathrm{~kg} \mathrm{DM} \mathrm{ha}^{-1}$. In addition, it promoted an increase in the participation of buffelgrass in the floristic composition, increasing its involvement in the area to around $74 \%$ at the maximum dose of phosphorus used. Thus, phosphate fertilisation at up to $100 \mathrm{~kg}$ of $\mathrm{P}_{2} \mathrm{O}_{5}$ ha $^{-1}$ year ${ }^{-1}$, together with grazing exclusion, can help to recover the Caatinga enriched with buffelgrass and optimise its use by reducing the formation of new grazing areas in the Caatinga.
\end{abstract}

Keywords: Floristic composition. Forage mass. Semiarid.

\section{DINÂMICA DA VEGETAÇÃO HERBÁCEA EM CAATINGA MANIPULADA COM EXCLUSÃO DE PASTEJO SOB ADUBAÇÃO FOSFATADA}

\begin{abstract}
RESUMO - O semiárido representa cerca de $70 \%$ da superfície do Nordeste brasileiro e o recurso forrageiro de maior expressão é a Caatinga, cobrindo aproximadamente $54 \%$ desta região. Porém, cerca de $40 \%$ dessa vegetação encontra-se em sucessão secundária e as áreas em processo de degradação de intensidade baixa a severa, já somam mais de 20 milhões de hectares, reflexo do uso intenso da terra, dentre elas o superpastejo. Objetivou-se avaliar a influência de diferentes doses de fósforo $\left(0,50\right.$ e $100 \mathrm{~kg}$ de $\mathrm{P}_{2} \mathrm{O}_{5} \mathrm{ha}^{-1}$ ano), em área de Caatinga manipulada, sem pastejo por quatro anos, sobre a dinâmica da vegetação herbácea em diferentes épocas do ano. O experimento foi conduzido na Unidade Acadêmica de Serra Talhada-UFRPE, durante os anos de 2015 a 2016. Foi utilizado delineamento em blocos casualizados, com três blocos e quatro repetições por bloco. A adubação fosfatada em áreas de exclusão ao pastejo promoveu aumento da massa de forragem do estrato herbáceo da Caatinga enriquecida, em todas as épocas de avaliação, com destaque para a época seca de 2016, que obeteve valores acima da média de $7950 \mathrm{~kg}$ de $\mathrm{MS}$ ha $^{-1}$. Promoveu aumento da participação do capim-buffel na composição florística, elevando sua participação na área em torno de 74\% para a dose máxima de fósforo utilizada. Neste sentido, a adubação fosfatada até $100 \mathrm{~kg}$ de $\mathrm{P}_{2} \mathrm{O}_{5}$ ha $^{-1}$ ano, juntamente com a exclusão ao pastejo, pode ajudar na recuperação da Caatinga enriquecida com capim-buffel e otimizar a sua utilização diminuindo a formação de novas áreas de pastejo na Caatinga.
\end{abstract}

Palavras-chave: Composição florística. Massa de forragem. Semiárido.

\footnotetext{
${ }^{*}$ Corresponding author

${ }^{1}$ Received for publication in 06/14/2017; accepted in 06/01/2018

Paper extracted from the Master Dissertation of the first author.

${ }^{2}$ Department of Animal Science, Universidade Federal Rural de Pernambuco, Recife, PE, Brazil; pedromouzinhont@hotmail.com ORCID: 0000-0002-1508-2008, marcio.cunha@ufrpe.br - ORCID: 0000-0002-1316-3218, mercia.vfsantos@ufrpe.br - ORCID: 00000002-7374-0910, janetegmoura@hotmail.com - ORCID: 0000-0002-0360-3291.

${ }^{3}$ Academic Unit of the Universidade Federal Rural de Pernambuco, Serra Talhada, PE, Brazil; evaristojorge@gmail.com - ORCID: 00000002-2206-414X.
} 


\section{INTRODUCTION}

Phosphorus $(\mathrm{P})$ has been one of the primary macronutrients that most often limits the forage yield (TAWARAYA; HIROSE; WAGATSUMA, 2012). Crop productivity may be limited by P deficiency by 30 to $40 \%$ of the world's arable land (VANCE; UHDE-STONE; ALLAN, 2003; BALEMI; NEGISHO, 2012; BALEMI; NEGISHO, 2012). Consequently, considering the importance of this element and because the soils have low $\mathrm{P}$ reserves readily available, a strategy for pasture recovery is phosphate fertilisation (ARAÚJO et al., 2010).

One approach to recover pasture is to exclude grazing areas, contributing to forage yield and resilience (MCSHERRY; RITCHIE, 2013). Consequently, to avoid degradation of grazing areas and to ensure equilibrium of the ecosystem, restoration of degraded vegetation is a common mode of control (WANG et al., 2014; LU et al., 2015). In the Brazilian northeast, the animal husbandry is extensive and supported by the Caatinga vegetation, represented by shrub, tree and herbaceous species, with a predominance of xerophytic and deciduous species (MARINHO et al., 2016).

The disordered increase in land use intensity is a threat to the Caatinga (RIBEIRO et al., 2015). Therefore, these pasture maintenance strategies are of fundamental importance. The Caatinga is one of the largest seasonal dry tropical forests in the world (MILES et al., 2006) and occupies an area of $844.453 \mathrm{~km}^{2}$, or $54.53 \%$ of the $1,548,672 \mathrm{~km}^{2}$ of the total area of the region (IBGE, 2013).

The extractivist form of extensive cattle ranching has increased the degraded pasture areas in the Brazilian semi-arid, where they vary from high to moderate, and can significantly alter plant productivity and botanical composition over time (SANTOS et al., 2010). Besides the aridity of the climate (due to the low rainfall index) and high potential rates of evapotranspiration, which reach 1500 to $2000 \mathrm{~mm} \mathrm{year}^{-1}$, the irregular rainfall distribution characterise the Brazilian semi-arid region (VELLOSO; SAMPAIO; PAREYN, 2002). Arid and semi-arid areas have some of the world's most fragile ecological and water resource systems (YE et al., 2015).

The exclusion of grazing combined with phosphate fertilisation has been shown to aid in the recovery of pasture grown at the beginning of degradation in the Agreste of Pernambuco (SILVA et al., 2004). Another study verified that after 1 year of grazing exclusion, but without phosphate fertilisation, in a Caatinga area with a predominance of native grasses (Chloris orthonoton Doell and
Brachiaria plantaginea (Link) Hitchc.) that these species had decreased participation in the botanical composition of the pasture, and there was a tendency of return of the ecological site to the climax of the Caatinga (SILVA et al., 2011). In this context, it is important to know the effect of phosphate fertilisation on manipulated Caatinga (thinned and enriched with exotic herbaceous species) that has excluded grazing for a prolonged period.

Thus, this work aimed to evaluate the influence of phosphate fertilisation (applied at 0, 50 and $100 \mathrm{~kg}$ of $\mathrm{P}_{2} \mathrm{O}_{5} \mathrm{ha}^{-1}$ year $^{-1}$ ) on the dynamics of Caatinga vegetation manipulated under grazing exclusion.

\section{MATERIAL AND METHODS}

The research occurred at the Academic Unit of the Federal Rural University of Pernambuco, in Serra Talhada, Brazil. The experimental area was an area of Caatinga thinned but with the maintenance of the mororó (Bauhinia cheilantha (Bong.) Steud.) and enriched with buffelgrass (Cenchrus ciliaris L.) and sabi grass (Urochloa mosambicensis (Hack.) Dandy), for pastoral purposes, planted as seeds in the 80 s. This area had been grazed by cattle over the years, without control of grazing pressure.

The experimental area $\left(7,200 \mathrm{~m}^{2}\right)$ has the geographic coordinates of $7^{\circ} 57^{\prime} 41^{\prime \prime} \mathrm{S}$, and $38^{\circ}$ $17^{\prime} 868^{\prime \prime} \mathrm{W}$ ), an average altitude of $515 \mathrm{~m}$, and possessed three blocks with four paddocks, totalling 12 plots of $584 \mathrm{~m}^{2}(20 \mathrm{~m} \times 29.2 \mathrm{~m})$.

The local climate, according to the Köppen classification, is of the type $B S w h$, denominated as semi-arid, hot and dry, with summer rains, annual thermal averages over $25{ }^{\circ} \mathrm{C}$ (MELO et al., 2008) and an average yearly rainfall of $642.1 \mathrm{~mm}$. Irregular rains occur in the region but are mostly concentrated in the first half of the year, with average high temperatures close to $24.8{ }^{\circ} \mathrm{C}$, and a relative humidity of the low air of around $62.5 \%$ (SILVA et al., 2015).

Figure 1 presents the rainfall of the years 2015 and 2016, together with the typical climatology of the municipality of Serra Talhada, obtained at an automatic station of the National Meteorological Institute (INMET), located $700 \mathrm{~m}$ from the experimental site.

The research considered two evaluation periods per year, based on the precipitation data: the rainy season (1st semester), which has the highest cumulative precipitation, and the dry season (2nd semester), with a relatively lower precipitation intensity. Moreover, the evaluations occurred bimonthly, totalling three assessments per period. 


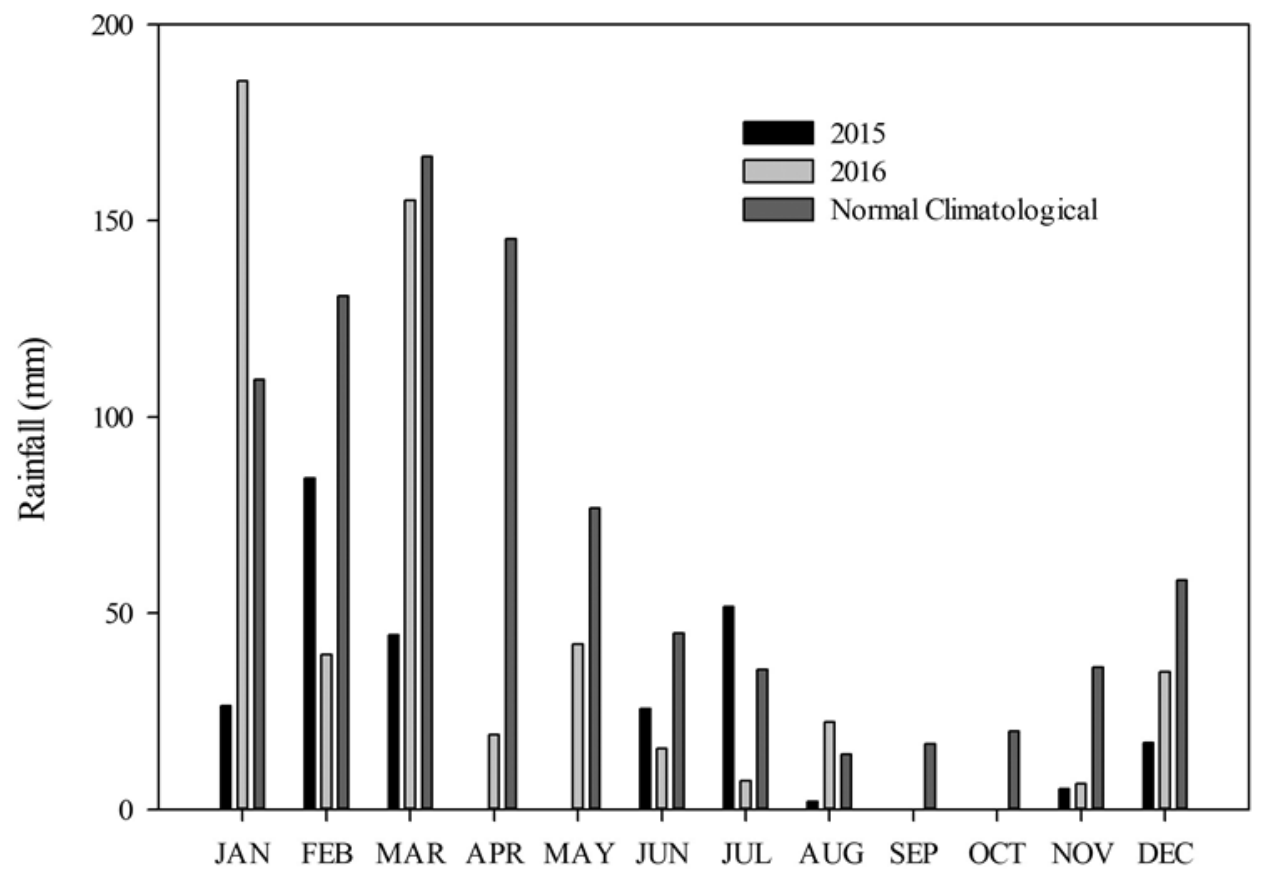

Months

Figure 1. Rainfall (mm) over the experimental period (2015 and 2016) and climatological normal of the municipality of Serra Talhada-PE, Brazil. Source: Pernambuco State Agency for Water and Climate (APAC), National Institute of Meteorology (INMET) and Department of Atmospheric Sciences (DCA - Federal University of Campina Grande).

The accumulated precipitation for the year 2015 was around $256.81 \mathrm{~mm}$. Of this total, $181 \mathrm{~mm}$ fell in the 1 st semester and $75.8 \mathrm{~mm}$ in the $2 \mathrm{nd}$ semester, respectively. More rainfall occurred in 2016 than 2015 , totalling $527.80 \mathrm{~mm}$, with 456.8 $\mathrm{mm}$ accumulated in the 1st semester and $29.4 \mathrm{~mm}$ in the 2nd semester.

As recommended by the Food and Agriculture Organisation (FAO), we used the Penman-Monteith/FAO-56 equation for calculating the reference evapotranspiration (ALLEN et al., 1998), with the assistance of REF-ET software (ALLEN, 2000). The reference evapotranspirations obtained during the evaluation periods were $901 \mathrm{~mm}$ in the rainy season of $2015,1087 \mathrm{~mm}$ in the dry season of 2015, $941 \mathrm{~mm}$ in the rainy season of 2016, and $800 \mathrm{~mm}$ in the dry season of 2016. Thus, there were higher evapotranspiration rates in 2015 than 2016, especially in the dry season of 2015, where the reference evapotranspiration reached values above $1000 \mathrm{~mm}$. The rainfall in the same period was only $75 \mathrm{~mm}$, confirming the water deficit in the region, where the atmospheric demand was almost 15 times greater than the accumulated rainfall in the same period.

The mean temperature $\left({ }^{\circ} \mathrm{C}\right)$ and relative humidity (\%) data during the experimental period, obtained through the INMET and APAC (Pernambuco State Agency for Water and Climate) automatic stations, ranged from 26 to $27{ }^{\circ} \mathrm{C}$ and from $47 \%$ to $60 \%$, respectively, with comparatively lower relative humidity obtained in the dry season of the evaluation.

The soil fertility was analysed in the laboratory of the Agronomic Institute of Pernambuco (IPA), Brazil, and presented the following chemical characteristics: $86.50 \pm 24.50$ mg dm${ }^{-3} \mathrm{P}$ (Mehlich-1); $8.72 \pm 1.79 \mathrm{cmolc} \mathrm{dm}^{-3} \mathrm{Ca}$; $1.60 \pm 0.86 \mathrm{cmolc} \mathrm{dm}^{-3} \mathrm{Mg} ; 0.04 \pm 0.00 \mathrm{cmolc} \mathrm{dm}^{-3}$ $\mathrm{Na} ; 0.65 \pm 0.06 \mathrm{cmolc} \mathrm{dm}^{-3} \mathrm{~K} ; 0.00 \pm 0.00$ cmolc dm ${ }^{-3} \mathrm{Al} ; 1.89 \pm 0.34 \mathrm{cmolc} \mathrm{dm}^{-3} \mathrm{H}, 4.47 \pm 0.16 \%$ of organic matter; $\mathrm{pH} 6.73 \pm 0.35 ; 11.00 \pm 0.93 \mathrm{cmolc}$ $\mathrm{dm}^{-3}$ for the sum of the soil bases; $12.90 \pm 0.69$ cmolc $\mathrm{dm}^{-3}$ for the cation exchange capacity, and $85.00 \pm 3.39 \%$ for base saturation.

According to work conducted by Soares (2015), based on the Brazilian Soil Classification System - SiBCS (EMBRAPA, 2013), the soil is a Habplic Habplico Ta Eutrophic, presenting a sandyloam texture (PREVEDELLO, 1996), eutrophic, weak acidity and medium-to-high fertility (IPA, 2008). No correction was made to the soil.

The research studied the vegetation of the Caatinga that had been protected from grazing for 4 years and fertilised with different doses of phosphate: 0,50 and $100 \mathrm{~kg}$ of $\mathrm{P}_{2} \mathrm{O}_{5}$ ha $^{-1}$ year $^{-1}$. The evaluations occurred at 60-day intervals throughout the years 2015 and 2016. Three areas (experimental plots) of $25 \mathrm{~m}^{2}(5 \mathrm{~m} \times 5 \mathrm{~m})$ delineated within each picket corresponded to each level of phosphate fertilisation and, thus, each picket presented the three doses of phosphate fertilisation. 
There was no incorporation of the $\mathrm{P}$ fertilisation in the soil, always occurring in March of 2013, 2014, 2015 and 2016, using the same dosages, according to the treatment and the experimental plot. The source of $\mathrm{P}\left(\mathrm{P}_{2} \mathrm{O}_{5}\right)$ used during the applications was the simple superphosphate (granulate). The applied amount of $\mathrm{P}$ was in accordance with the total $\mathrm{P}_{2} \mathrm{O}_{5}$ content in the phosphate fertiliser (i.e., 18\%). According to the data obtained from the soil chemical analysis, soil correction was not necessary.

To determine the floristic composition, an initial evaluation of the experimental area was done to identify the most frequent species in the pasture. The exsiccate production occurred, with plant material collected and sent to the Brazilian Semiarid Herbarium (HESBRA), of the Federal Rural University of Pernambuco, Brazil, to identify the species present in the area.

We used the method proposed by Mannetje and Haydock (1963), adapted by Jones and Hargreaves (1979), for estimated floristic composition. Thus, species present in a $1 \mathrm{~m} \times 1 \mathrm{~m}$ polyvinylchloride (PVC) cane frame, arranged randomly in each grazing exclusion area, received the ranks of 70,21 and $9 \%$ for those species whose participation in the pasture was in 1st, 2nd and 3rd place, respectively. Species with high dominance in the sample received a cumulative classification (more than one class attributed), corresponding to the 1 st and 2 nd places, for example, as modified by Jones and Hargreaves (1979).

We estimated the litter percentage $(0$ to $100 \%$, according to visual observation) and the height of the pasture in the same area delimited by the frame, to evaluate the floristic composition. All the plant material deposited on the surface of the soil, detached from the plants, was litter. We used a graded ruler to measure the height of the pasture, measuring two heights, one for the herbaceous stratum and the other for the arboreal-shrub stratum.

To determine the forage mass, the forage of the herbaceous stratum was cut into two areas of $0.25 \mathrm{~m}^{2}(0.5 \mathrm{~m} \times 0.5 \mathrm{~m})$ bounded by a PVC frame. The collected material was packed in properly identified paper bags, weighed and oven-dried under forced air at $55{ }^{\circ} \mathrm{C}$ for $72 \mathrm{~h}$. Shortly after, another weighing was performed to obtain the dry mass (DM). The forage density ( $\mathrm{kg} \mathrm{DM} \mathrm{ha}{ }^{-1} \mathrm{~cm}^{-1}$ ) was determined by dividing the dry weight of the forage mass $\left(\mathrm{kg} \mathrm{DM} \mathrm{ha}^{-1}\right)$ by the height of the herbaceous stratum.

The experimental design was in randomised blocks, with three repetitions and four replicates within each block (set of four paddocks). The mean was calculated for the replicates within each block. The evaluation months were grouped at times of the year (rainy and dry), and the evaluations were performed bimonthly (60-day intervals). Statistical analyses were performed using the PROC MIXED procedure (LITTELL; HENRY; AMMERMAN,
1998), with the aid of SAS University. The times of the years of 2015 and 2016 were considered as measures repeated in time. The effects of phosphate fertilisation, the times of the year, the interaction of phosphate fertilisation $\times$ times of the year, and the effect of the experimental blocks were considered in the analysis of variance (ANOVA). To compare the means at the time of the year, Tukey's test at $5 \%$ of probability was used by LSMEANS adjusted for Tukey, using SAS University. For the study of the effect of phosphate fertilisation, regression analysis was performed at 5\% probability, using SigmaPlot for Windows software version 12.0.

\section{RESULTS AND DISCUSSION}

In the floristic composition of the studied area, it was verified that 31 plant species belonging to 18 families were present, indicating floristic diversity in the area, despite being an area enriched for pastoral purposes (Table 1).

Alves et al. (2010), when investigating the natural regeneration of a Caatinga area in PombalPB, under grazing of cattle in the dry period, identified 13 species and 7 botanical families. In an area with three levels of disturbance (I - environment with intense exploitation of the herbaceous and arboreal stratum; II - characterised by a lower level of disturbance than the previous one, without exploitation of the arboreal stratum, and III constituted by areas of the remaining forest that was in a better state of conservation) in the Agreste region of Paraiba, Brazil, 17 families and 26 regenerating species were found (PEREIRA et al., 2001). Andrade et al. (2007) studied abandoned fields (about 30 years old) of sisal (Agave sisalana Perrine ex Engelm.) in Paraíba, Brazil, and verified 16 botanical families and 31 species, with more species belonging to the family Euphorbiaceae.

In the present research, despite the high number of species, there was dominance in the area of the $C$. ciliaris L. (buffelgrass), U. mosambicensis (Hack.) Dandy (sabi grass), B. cheilantha (Bong.) Steud. (mororó), Capparis flexuosa L. (brave bean) and Melochia tomentosa L. (capa-bode).

There was a significant effect $(\mathrm{P}<0.05)$ of the phosphate fertilisation, but only on the participation of buffelgrass in the floristic composition. As the $\mathrm{P}$ fertilisation increased, there was an increase in the involvement of buffelgrass in the floristic composition (Figure 2). Consequently, the dose of $100 \mathrm{~kg} \mathrm{P}_{2} \mathrm{O}_{5}$ ha $^{-1}$ year $^{-1}$ provided a $74 \%$ increase in the participation of this species in the floristic composition of the area, thereby contributing to the maintenance and expansion of forage mass, since buffelgrass is a species resistant to low precipitations. 
Table 1. Family, scientific name and of the plant species present in the experimental área.

\begin{tabular}{|c|c|c|}
\hline Family & scientific name & Common name \\
\hline Anacardiaceae & Myracrodruon urundeuva Allemão & Aroeira \\
\hline Apocynaceae & Aspidosperma pyrifolium Mart. & Pereiro \\
\hline Bignoniaceae & Handroanthus impetiginosus (Mart. ex DC.) Mattos & ipê-rosa, ipê-roxo \\
\hline Bignoniaceae & Stereospermum colais Mabb. & - \\
\hline Cactaceae & Cereus jamacaru. DC. & mandacaru \\
\hline Caesalpinioideae & Caesalpinia pyramidalis Tul. & catingueira \\
\hline Capparaceae & Capparis flexuosa L. & feijão-bravo \\
\hline Convolvulaceae & Merremia aegyptia (L.) Urb. & jitirana-cabeluda \\
\hline Euphorbiaceae & Croton sonderianus Müll. Arg. & marmeleiro \\
\hline Euphorbiaceae & Ditaxis desertorum (Müll. Arg.) Pax \& K. Hoffm. & - \\
\hline Euphorbiaceae & Euphorbia heterophylla L. & leiteira \\
\hline Euphorbiaceae & Jatropha molíssima (Pohl) Baill. & pinhão-bravo \\
\hline Euphorbiaceae & Manihot glaziovii Müll. Arg. & maniçoba \\
\hline Leguminosae & Indigofera suffruticosa Mill. & anileira \\
\hline Fabaceae & Mimosa sensitiva L. & malícia \\
\hline Fabaceae & Rhynchosia minima (L.) DC. & - \\
\hline Gramineae & Cenchrus ciliaris L. & capim-buffel \\
\hline Gramineae & Urochloa mosambicensis Hack. & capim-corrente \\
\hline Leguminosae & Bauhinia cheilantha Steud. & mororó \\
\hline Leguminosae & Mimosa tenuiflora Benth. & jurema-preta \\
\hline Leguminosae & Senna uniflora (Mill.) H.S. Irwin \& Barneby & mata-pasto \\
\hline Malvaceae & Herissantia crispa (L.) Brizicky & malva \\
\hline Malvaceae & Sida spinosa L. & $\begin{array}{c}\text { guanxuma; malva- } \\
\text { lanceta }\end{array}$ \\
\hline Malvaceae & Sida spp L. & vassourinha \\
\hline Malpighiaceae & Diplopterys lutea (Griseb.) W.R. Anderson \& C. Davis & - \\
\hline Leguminosae & Anadenanthera macrocarpa (Benth) Brenan & angico \\
\hline Poaceace & Aristida setifolia Kunth & capim-panasco \\
\hline Rhamnaceae & Ziziphus joazeiro Mart. & joazeiro \\
\hline Rubiaceae & Diodella teres (Walter) Small & - \\
\hline Sterculiaceae & Melochia tomentosa $\mathrm{L}$. & capa-bode \\
\hline Sterculiaceae & Waltheria macropoda Turcz. & malva-branca \\
\hline
\end{tabular}

Source: Herbarium of the Brazilian Semi-Arid (HESBRA), adapted of Moura (2017).

The other species studied were not influenced $(\mathrm{P}>0.05)$ by phosphate fertilisation. In other native pasture types, this result was also verified. Previously, Oliveira et al. (2015b) confirmed that P applied at $249 \mathrm{~kg} \mathrm{ha}{ }^{-1}$, distributed throughout the winter of 1998, 2002, 2010 and 2012, in areas of native pasture fields in Rio Grande do Sul, Brazil, did not affect species diversity in the area studied during the experimental period.

The buffelgrass and the sabi grass had greater participation in the floristic composition of the studied area than the other evaluated species. Together they represented $67 \%, 72 \%$ and $77 \%$, at the fertilisation rates of 0,50 and $100 \mathrm{~kg} \mathrm{P}_{2} \mathrm{O}_{5}$ ha $^{-1}$ year
1, respectively. Thus, as phosphate fertilisation increased, the participation of these grasses also increased in the area.

The participation of buffelgrass was highest $(\mathrm{P}<0.05)$ in the dry season of 2016 (Figure 3). Possibly, the greater involvement of the species in this period was due to the greater rainfall that occurred in the rainy season of 2016. It is also possible that over time the species increased its dominance over the other species, due to its morphophysiological mechanisms (Figure 3). The buffelgrass responds rapidly to low-intensity precipitation events (LAZARIDES; COWLEY; HOHNEN, 1997). 


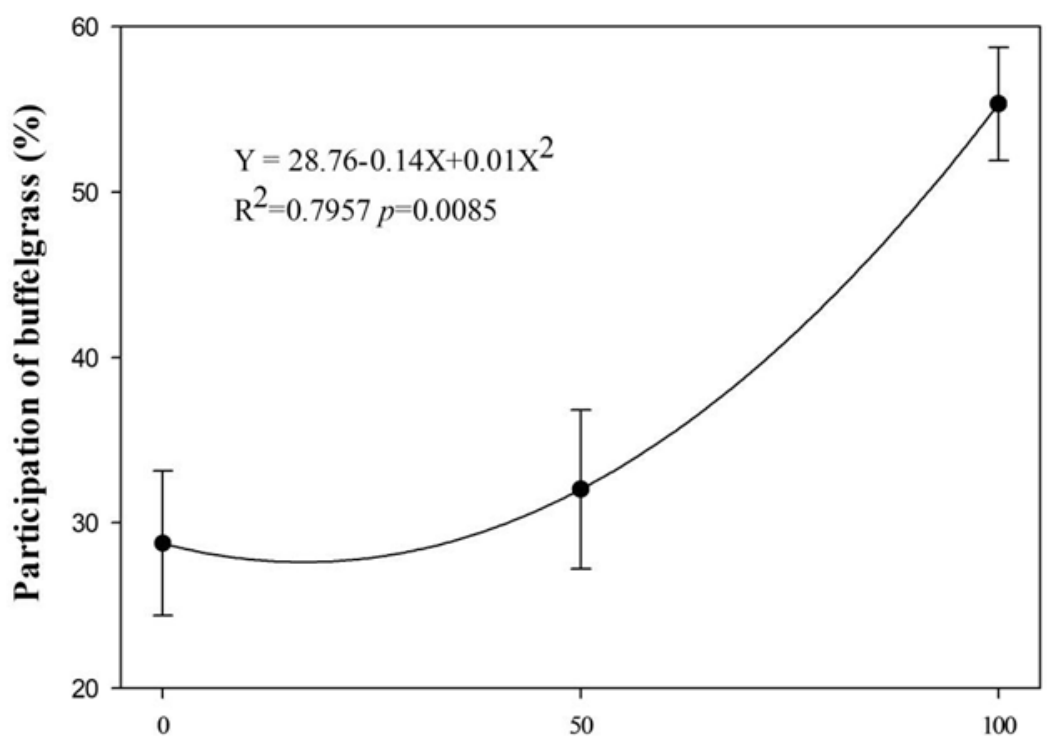

Dose of phosphate fertilization (kg of $\mathrm{P}_{2} \mathrm{O}_{5}$.ha. year ${ }^{-1}$ )

Figure 2. Participation (\%) of buffelgrass (Cenchrus ciliaris L.) in floristic composition, in Caatinga manipulated without grazing under phosphate fertilization.

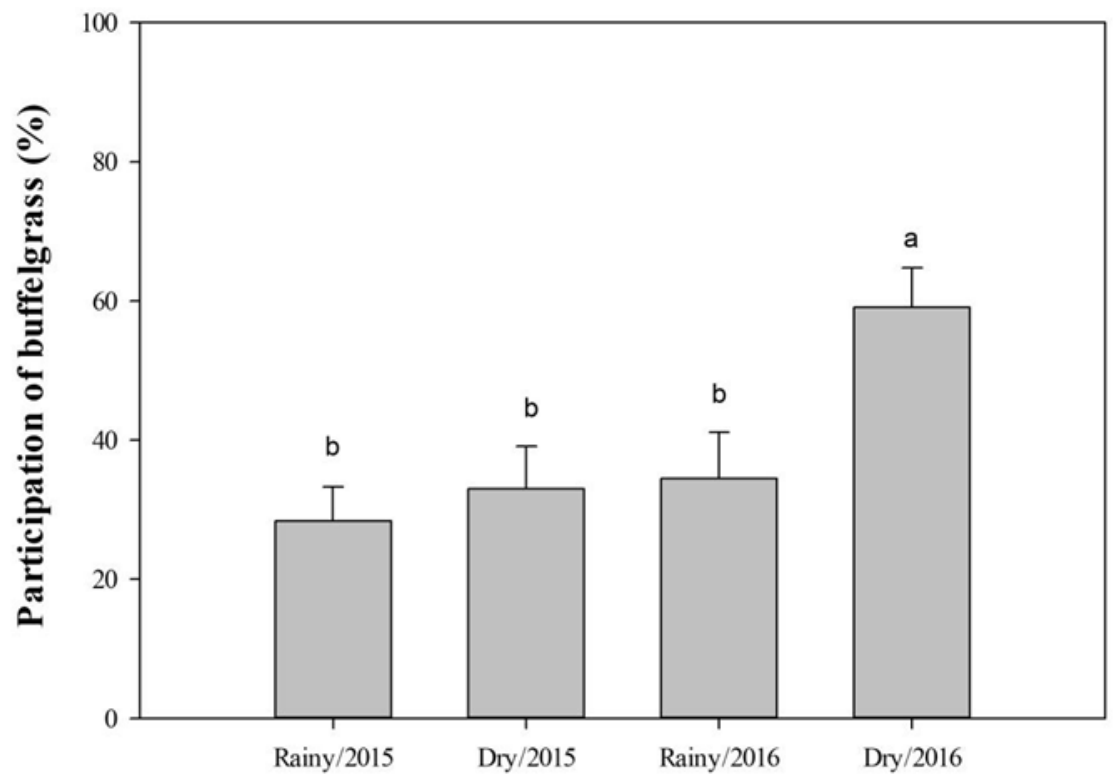

Times of the year

Figure 3. Participation (\%) of buffelgrass (Cenchrus ciliaris L.) in floristic composition, at different times of the year, in the manipulated and non-grazing Caatinga. Error bars with equal letters do not differ by the Tukey test at $5 \%$ probability. $\mathrm{CV}(\%)=37.82 \%$.

The participation of sabi grass in the floristic composition was influenced $(\mathrm{P}<0.05)$ by the interaction between phosphate fertilisation and times of the year (Table 2), such that the increase in the dose of phosphate fertilisation reduced the participation of this species in the Caatinga, but only in the rainy times of 2015 and 2016. However, regarding the time of year, within each dose of phosphate fertilisation, during the rainy and dry time of 2015, there was greater participation of sabi grass in the absence of phosphate fertilisation. Still, when a dose of $100 \mathrm{~kg} \mathrm{P}_{2} \mathrm{O}_{5}$ ha $^{-1}$ year ${ }^{-1}$ was used, the lowest participation of the sabi grass was the dry time of 2016, whereas, in the rainy time of that year, there was less participation of this grass in the area. These results are due to the dynamics of the contribution of the other species in the area. 
Table 2. Participation (\%) of sabi grass (Urochloa mosambicensis Hack.) In floristic composition at different times of the year, under manipulated Caatinga and without grazing, under phosphate fertilization.

\begin{tabular}{|c|c|c|c|c|}
\hline \multirow{3}{*}{ Times of the year } & \multicolumn{3}{|c|}{ Phosphate fertilization } & \multirow{3}{*}{ Polynomial effect of doses of phosphate fertilization } \\
\hline & 0 & 50 & 100 & \\
\hline & \multicolumn{3}{|c|}{ kg of $\mathrm{P}_{2} \mathrm{O}_{5}$ ha $^{-1}$ year $^{-1}$} & \\
\hline Rainy/2015 & $47.06 \mathrm{a}$ & $44.71 \mathrm{a}$ & $26.51 b$ & $\mathrm{Y}=47.05+0.12 \mathrm{X}-0.001 \mathrm{X}^{2}\left(\mathrm{R}^{2}=0.73\right)$ \\
\hline Dry/2015 & $46.12 \mathrm{a}$ & $47.05 \mathrm{a}$ & $27.59 b$ & $Y=49.25$ \\
\hline Rainy/2016 & $31.28 \mathrm{~b}$ & $43.70 \mathrm{a}$ & $13.83 \mathrm{c}$ & $\mathrm{Y}=31.28+0.67 \mathrm{X}-0.001 \mathrm{X}^{2}\left(\mathrm{R}^{2}=0.79\right)$ \\
\hline Dry/2016 & $31.06 \mathrm{~b}$ & $46.92 \mathrm{a}$ & $45.13 \mathrm{a}$ & $Y=41.03$ \\
\hline
\end{tabular}

Means followed by lower case letters in the column do not differ by the Tukey test at $5 \%$ probability. CV $(\%)=16.62 \%$.

There was a significant effect $(\mathrm{P}<0.05)$ of the interaction between phosphate fertilisation and the times of the year on the participation of other species (Table 3), with the increase in phosphorus fertilisation promoting a decrease in the involvement of these species in the area, except in the dry season of 2016. However, as the P dose increased, there was greater participation of buffelgrass, making it more competitive with these species, that are annual species.

Table 3. Participation (\%) of other herbaceous species in the floristic composition at different times of the year, under manipulated and non-grazing Caatinga, under phosphate fertilization.

\begin{tabular}{|c|c|c|c|c|}
\hline \multirow{3}{*}{ Times of the year } & \multicolumn{3}{|c|}{ Phosphate fertilization } & \multirow{3}{*}{ Polynomial effect of doses of phosphate fertilization } \\
\hline & 0 & 50 & 100 & \\
\hline & \multicolumn{3}{|c|}{ kg of $\mathrm{P}_{2} \mathrm{O}_{5}$ ha $^{-1}$ year $^{-1}$} & \\
\hline Rainy/2015 & $22.56 b$ & $12.41 \mathrm{~b}$ & $8.14 b$ & $\mathrm{Y}=22.55-0.26 \mathrm{X}+0.0012 \mathrm{X}^{2}\left(\mathrm{R}^{2}=0.73\right)$ \\
\hline Dry/2015 & $17.36 \mathrm{~b}$ & $9.28 b$ & $3.08 \mathrm{~b}$ & $\mathrm{Y}=17.36-0.18 \mathrm{X}+0.0004 \mathrm{X}^{2}\left(\mathrm{R}^{2}=0.85\right)$ \\
\hline Rainy/2016 & $34.42 \mathrm{a}$ & $24.85 \mathrm{a}$ & $16.58 \mathrm{a}$ & $\mathrm{Y}=34.20-0.18 \mathrm{X}\left(\mathrm{R}^{2}=0.59\right)$ \\
\hline Dry/2016 & $4.13 c$ & $7.68 \mathrm{~b}$ & $7.93 b$ & $Y=6.58$ \\
\hline
\end{tabular}

Means followed by lower case letters in the column do not differ by the Tukey test at $5 \%$ probability. CV $(\%)=$ $34.39 \%$.

Regarding the times of the year, the participation of these species was highest in the rainy time of 2016, possibly due to the higher rainfall. Also, in the absence of fertilisation, there was less participation of these species in the dry season of 2016 (Table 3). These species present a short cycle and, as the rains decrease, they tend to disappear during periods of drought (PEREIRA FILHO;

\section{VIEIRA, 2006).}

There was no significant effect $(\mathrm{P}>0.05)$ of the phosphate fertilisation on the percentage of uncovered soil and the height of the arboreal stratum. These characteristics were influenced $(\mathrm{P}<0.05)$ only by the times of the year. Over time, the percentage of uncovered soil increased, reaching $21.98 \%$ in the dry season of 2016 (Table 4).

Table 4. Percentage of uncovered soil and height of the arboreal strata, at different times of the year, in a manipulated and non-grazing Caatinga.

\begin{tabular}{ccc}
\hline Times of the year & Uncovered soil $(\%)$ & Height of the arboreal strata $(\mathrm{m})$ \\
\hline Rainy/2015 & $11.13 \mathrm{c}$ & $1.41 \mathrm{~b}$ \\
Dry/2015 & $12.36 \mathrm{c}$ & $1.38 \mathrm{~b}$ \\
Rainy/2016 & $16.46 \mathrm{~b}$ & $1.75 \mathrm{~b}$ \\
Dry/2016 & $21.98 \mathrm{a}$ & $2.65 \mathrm{a}$ \\
\hline Mean & 15.48 & 1.80 \\
CV $(\%)$ & 31.22 & 36.10 \\
\hline
\end{tabular}

Means followed by lower case letters in the column do not differ by the Tukey test at $5 \%$ probability. 
This fact can be justified by the growth habit of the buffelgrass (bunchgrasses) since this species also increased its participation over time. Furthermore, in the dry season, the herbaceous stratum of the vegetation tends to decrease and, with this, there is a greater perception of the soil in the areas. Oliveira et al. (2015a), in an area of native pasture with an introduction of buffelgrass and sabi grass, in Serra Talhada, Brazil, obtained results similar to the present study, in which the average percentage of the uncovered soil of the evaluated pasture was $26 \%$.

The height of the arboreal stratum also increased over time and was highest in the dry season of 2016 (Table 4). This result reinforces the fact that over time, native tree vegetation tends to continue to develop and grow, even in a thinned environment enriched with exotic grasses in the
Caatinga (Table 4).

There was a significant effect $(\mathrm{P}<0.05)$ of the interaction between phosphate fertilisation and time of year on the height of the herbaceous stratum. In this sense, phosphate fertilisation did not influence the height of the herbaceous stratum at any time of the year (Table 5).

For the effect of the time of year within each dose of phosphate fertilisation, in the absence of phosphate fertilisation, there were no differences in the height of the herbaceous stratum. At the dose of $50 \mathrm{~kg} \mathrm{P}_{2} \mathrm{O}_{5}$ $\mathrm{ha}^{-1}$ year $^{-1}$, the highest heights were in the rainy season. In comparison, at the dose of $100 \mathrm{P}_{2} \mathrm{O}_{5} \mathrm{ha}^{-1}$ year $^{-1}$, in addition to the rainy time, the height of the herbaceous stratum was also higher in the dry season of 2016 compared to the dry season of 2015. Thus, phosphate fertilisation modifies the height of the herbaceous stratum over time.

Table 5. Height $(\mathrm{cm})$ of the herbaceous stratum at different times of the year, in Caatinga, manipulated and without grazing, under phosphate fertilization.

\begin{tabular}{|c|c|c|c|c|}
\hline \multirow{3}{*}{ Times of the year } & \multicolumn{3}{|c|}{ Phosphate fertilization } & \multirow{3}{*}{ Polynomial effect of doses of phosphate fertilization } \\
\hline & 0 & 50 & 100 & \\
\hline & \multicolumn{3}{|c|}{ kg of $\mathrm{P}_{2} \mathrm{O}_{5}$ ha $^{-1}$ year $^{-1}$} & \\
\hline Rainy/2015 & $51.74 \mathrm{a}$ & $47.99 \mathrm{a}$ & $51.32 \mathrm{a}$ & $\mathrm{Y}=50.35$ \\
\hline Dry/2015 & $30.63 a$ & $27.85 \mathrm{c}$ & $30.49 b$ & $Y=29.66$ \\
\hline Rainy/2016 & $50.28 \mathrm{a}$ & $52.64 \mathrm{a}$ & $51.56 \mathrm{a}$ & $\mathrm{Y}=51.49$ \\
\hline Dry/2016 & $51.31 \mathrm{a}$ & $38.41 \mathrm{~b}$ & $51.46 \mathrm{a}$ & $\mathrm{Y}=47.06$ \\
\hline
\end{tabular}

Means followed by lower case letters in the column do not differ by the Tukey test at $5 \%$ probability. CV $(\%)=$ $19.69 \%$

There was a significant effect $(\mathrm{P}<0.05)$ of the phosphate fertilisation interaction and the times of the year on the litter percentage. Fertilisation only influenced the percentage of litter in the dry season of 2016, where the percentage of litter decreased at the dose of $50 \mathrm{~kg} \mathrm{P}_{2} \mathrm{O}_{5}$ ha $^{-1}$ year $^{-1}$, relative to the absence of phosphate fertilisation and increased again at the highest dose. Possibly, a higher litter deposition occurred in the absence of fertilisation as a result of the lower energy input to the plants and, at the dose of $100 \mathrm{~kg} \mathrm{P}_{2} \mathrm{O}_{5}$ ha $^{-1}$ year $^{-1}$, as a result of the higher production of biomass stimulated by $\mathrm{P}$, respectively (Table 6).

Table 6. Percentage of litter, at different times of the year, in Caatinga, manipulated and without grazing, under phosphate fertilization.

\begin{tabular}{|c|c|c|c|c|}
\hline \multirow{3}{*}{ Times of the year } & \multicolumn{3}{|c|}{ Phosphate fertilization } & \multirow{3}{*}{ Polynomial effect of doses of phosphate fertilization } \\
\hline & 0 & 50 & 100 & \\
\hline & \multicolumn{3}{|c|}{$\mathrm{kg}$ of $\mathrm{P}_{2} \mathrm{O}_{5}$ ha $^{-1}$ year $^{-1}$} & \\
\hline Rainy/2015 & $12.92 \mathrm{~d}$ & $12.78 \mathrm{c}$ & $15.56 \mathrm{c}$ & $Y=13.75$ \\
\hline Dry/2015 & $19.65 \mathrm{c}$ & $19.44 b$ & $16.81 \mathrm{c}$ & $Y=18.63$ \\
\hline Rainy/2016 & $37.85 b$ & $41.32 \mathrm{a}$ & $33.33 b$ & $Y=37.50$ \\
\hline Dry/2016 & $61.35 \mathrm{a}$ & $45.58 \mathrm{a}$ & $52.92 \mathrm{a}$ & $\mathrm{Y}=61.35+0.26 \mathrm{X}-0.0046 \mathrm{X}^{2}\left(\mathrm{R}^{2}=0.79\right)$ \\
\hline
\end{tabular}

Means followed by lower case letters in the column do not differ by the Tukey test at $5 \%$ probability. CV $(\%)=$ $12.96 \%$. 
Regarding the times of the year, within each dose of phosphate fertilisation, in the dry season of 2016 , in the absence of fertilisation and at the dose of $100 \mathrm{~kg} \mathrm{P} \mathrm{O}_{5} \mathrm{ha}^{-1}$ year $^{-1}$, the percentage of litter was higher compared to other times. However, at the dose of $50 \mathrm{~kg} \mathrm{P}_{2} \mathrm{O}_{5} \mathrm{ha}^{-1}$ year $^{-1}$, the percentage of litter was highest in the rainy and dry season of 2016.

According to Bertol, Mafra and Cogo (2006), the biomass at the soil surface is of fundamental importance, especially in areas destined to grazing, as it dissipates the mechanical energy from the pressure of the animal hooves during grazing and also the kinetic energy of the raindrops, decreasing the erosion. In addition, Costa (2000) mentions that a high percentage of uncovered soil favours an increase in the population of invasive plants, increasing the probability of leaching of most of the nutrients available in the soil, allowing a significant loss of soil fertility in the area. Lopes et al. (2009) and Lima et al. (2015) observed a significant correlation between litter deposition and precipitation, with the highest deposition at the beginning of the dry period.

There was a significant effect $(\mathrm{P}<0.05)$ of the interaction between phosphate fertilisation and time of year on the forage mass (Table 7). Phosphate fertilisation increased the forage mass in the rainy and dry seasons of 2015, as well as the dry season of 2016. In the dry season of 2016 , there was no influence of the phosphate fertilisation on the forage mass, possibly due to the high rainfall in the period, which led the vegetation to produce high biomass, even in the absence of phosphate fertilisation.

Table 7. Forage mass (kg of DM.ha ${ }^{-1}$ ) in the herbaceous stratum at different times of the year, under manipulated and nongrazing Caatinga, under phosphate fertilization.

\begin{tabular}{ccccc}
\hline \multirow{2}{*}{ Times of the year } & \multicolumn{3}{c}{ Phosphate fertilization } & \multirow{2}{c}{$\begin{array}{c}\text { Polynomial effect of doses of phosphate } \\
\text { fertilization }\end{array}$} \\
\cline { 2 - 4 } & \multicolumn{3}{c}{0} & \multicolumn{2}{c}{50} & 100 & \multirow{2}{c}{\begin{tabular}{c} 
kg of $\mathrm{P}_{2} \mathrm{O}_{5} \mathrm{ha}^{-1} \mathrm{year}^{-1}$ \\
\cline { 2 - 4 }
\end{tabular}} \\
\cline { 2 - 4 } Rainy/2015 & $3526.67 \mathrm{~b}$ & $4005.56 \mathrm{~b}$ & $5185.56 \mathrm{c}$ & $\mathrm{Y}=3526.67+2.57 \mathrm{x}+0.14 \mathrm{x}^{2}\left(\mathrm{R}^{2}=0.79\right)$ \\
Dry/2015 & $2410.00 \mathrm{c}$ & $2287.78 \mathrm{c}$ & $3467.67 \mathrm{~d}$ & $\mathrm{Y}=2410-15.47 \mathrm{x}+0.26 \mathrm{x}^{2}\left(\mathrm{R}^{2}=0.67\right)$ \\
Rainy/2016 & $10658.78 \mathrm{a}$ & $11454.00 \mathrm{a}$ & $11812.16 \mathrm{a}$ & $\mathrm{Y}=11.308 .31$ \\
Dry/2016 & $4011.03 \mathrm{~b}$ & $4479.37 \mathrm{bB}$ & $7954.01 \mathrm{~b}$ & $\mathrm{Y}=3509.98 \mathrm{x}+39.43\left(\mathrm{R}^{2}=0.51\right)$ \\
\hline
\end{tabular}

Means followed by lower case letters in the column do not differ by the Tukey test at $5 \%$ probability. CV $(\%)=18.30 \%$.

Santos et al. (2010) noted the forage mass of the Caatinga varies, especially, according to the time of year, Caatinga type, grazing pressure, plant density, and the method of management and evaluation, among others. The forage mass in the current research was higher than that found by Oliveira et al. (2015a), where the total forage mass ranged from $422 \pm 42$ to $1,262 \pm 95 \mathrm{~kg} \mathrm{DM} \mathrm{ha}^{-1}$ from January 2011 to January 2012, in an area of native pasture enriched in the sertão of Pernambuco, Brazil. The forage mass reported by Moreira et al. (2006) and Ydoyaga-Santana et al. (2011), with a mean of $3,426 \mathrm{~kg} \mathrm{DM} \mathrm{ha}{ }^{-1}$, was comparatively lower; however, in these works, the areas were under grazing.

The forage mass present in the plots represents the accumulated mass during 4 years of grazing exclusion and reflects the free growth dynamics of herbaceous plants, mainly buffelgrass and sabi grass.

The time of year (Figure 4) and phosphate fertilisation (Figure 5) influenced $(\mathrm{P}<0.05)$ the forage density, but the interaction was not significant $(\mathrm{P}>0.05)$. The rainy season of 2016 presented the highest forage density, reaching $222 \mathrm{~kg} \mathrm{DM} \mathrm{cm}^{-1}$ ha 1 (Figure 4) since this period demonstrated the highest rainfall $(456 \mathrm{~mm})$ relative to the others.

The phosphate fertilisation provided an increase in forage density (Figure 5). According to Hodgson (1990), density usually has an inverse relationship with pasture height and can reach low levels even in more productive areas. Gonçalves et al. (2009) verified that with the increase of the pasture height, there was a significant reduction of the forage densities, in an area grazed by cattle. 


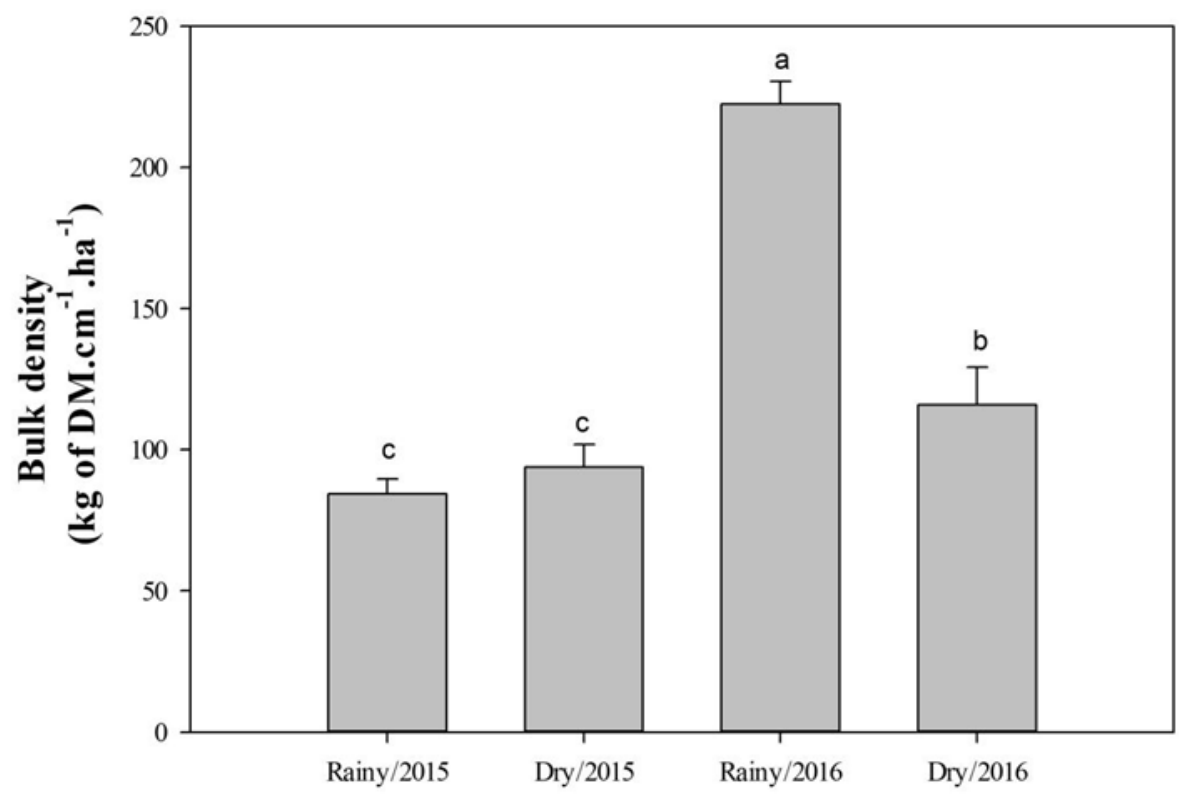

Times of the year

Figure 4. Bulk density in Caatinga area manipulated, without grazing, at different times of the year. Error bars with equal letters do not differ by the Tukey test at $5 \%$ probability. CV $(\%)=2.88 \%$.

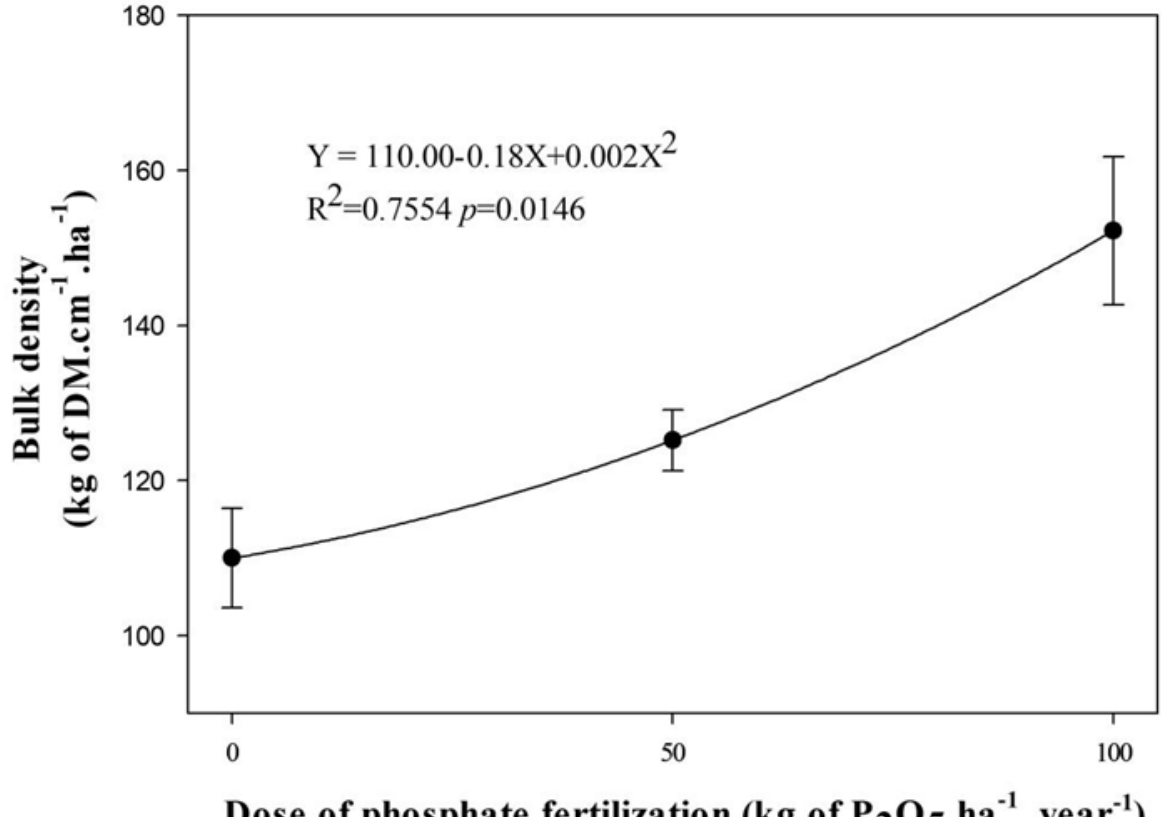

Figure 5. Bulk density in Caatinga manipulated and without grazing, under phosphate fertilization, Serra Talhada-PE. CV $(\%)=2.88 \%$.

The higher the forage density, the greater the auto-shading of the leaves, promoting an increase in respiratory rates and an increase in senescence. Thus, a comparatively higher forage density explains the greatest amount of litter at the highest dose of phosphate fertilisation in the dry season of 2016 (Table 6), which represents the vegetation with accumulated biomass for 4 years.

The results of the present study showed that grazing exclusion for more than 1 year in areas of the Caatinga manipulated and enriched with buffelgrass and sabi grass, combined with phosphate fertilisation, significantly increases the pasture mass and forage density, as it promotes participation of buffelgrass in the area. Therefore, the exclusion of grazing and application of phosphate fertilisation may be strategies to recover areas of Caatinga for pastoral purposes.

\section{CONCLUSIONS}

Rev. Caatinga, Mossoró, v. 31, n. 4, p. 1027 - 1039, out. - dez., 2018 
Phosphate fertilisation in grazing exclusion areas promotes an increase in the forage mass and density of the herbaceous stratum of the Caatinga enriched with buffelgrass and sabi grass. It also encourages the participation of buffelgrass in the floristic composition.

Specifically, phosphate fertilisation at up to $100 \mathrm{~kg} \mathrm{P}_{2} \mathrm{O}_{5}$ ha $^{-1}$ year $^{-1}$ can help the recovery of the Caatinga enriched with buffelgrass and avoid the formation of new pasture areas in this region.

\section{ACKNOWLEDGEMENTS}

To $\mathrm{CNPq}$, for the financing of the research that resulted in this article, as well as for the scholarship grants to the authors Márcio Vieira da Cunha and Mércia Virginia Ferreira da Cunha.

\section{REFERENCES}

ALLEN, R. G. et al. Crop evapotranspiration: Guidelines for computing crop water requirements. Rome: FAO, 1998. 300 p. (FAO - Irrigation and Drainage Paper, 56).

ALLEN, R. G. REF-ET: Reference evapotranspiration calculator - Version 2.1. Kimberly: Idaho University, 2000. 82 p.

ALVES, L. S. et al. Regeneração natural em uma área de caatinga situada no município de Pombal-PB, Brasil. Revista Verde de Agroecologia e Desenvolvimento Sustentável, Mossoró, v. 5, n. 2, p. 152-168, 2010.

ANDRADE, L. A. et al. Análise da vegetação sucessional em campos abandonados no agreste paraibano. Revista Brasileira de Ciências Agrárias, Recife, v. 2, n. 2, p. 135-142, 2007.

ARAÚJO, M. M. et al. Uso do fósforo em gramíneas e leguminosas cultivadas em Neossolo do semiárido. Agropecuária Científica no Semiárido, Campina Grande, v. 6, n. 1, p. 40-46, 2010.

BALEMI, T.; NEGISHO, K. Management of soil phosphorus and plant adaptation mechanisms to phosphorus stress for sustainable crop production: a review. Journal of Soil Science and Plant Nutrition, Temuco, v. 12, n. 3, p. 547-561, 2012.

BERTOL, I.; MAFRA, A. L.; COGO, N. P. Conservação do solo em pastagens. In: SIMPÓSIO SOBRE MANEJO DA PASTAGEM, 23., 2006, Piracicaba. Anais... Piracicaba: FEALQ, 2006. p. 139-163.
COSTA, N. L. Resposta de pastagens degradadas de Brachiaria brizantha cv. Marandu a doses de nitrogênio e fósforo. In: REUNIAO ANUAL DA SOCIEDADE BRASILEIRA DE ZOOTECNIA, 37., 2000, Viçosa. Anais... Viçosa: Sociedade Brasileira de Zootecnia, 2000. p. 131.

EMPRESA BRASILEIRA DE PESQUISA AGROPECUÁRIA - EMBRAPA. Sistema Brasileiro de Classificação de Solos. 3. ed. Rio de Janeiro, RJ: EMBRAPA Solos, 2013. 353 p.

GONÇALVES et al. Relações planta-animal em ambiente pastoril heterogêneo: processo de ingestão de forragem. Revista Brasileira de Zootecnia, Viçosa, v. 38, n. 9, p. 1655-1662, 2009.

HODGSON, J. Grazing management: science into practice. Longman Handbooks in Agriculture. New York: John Wiley \& Sons, 1990. 203 p.

INSTITUTO BRASILEIRO DE GEOGRAFIA E ESTATÍSTICA - IBGE. Mapa de Biomas e de Vegetação. Disponível em: <http:// www.ibge.gov.br/home/geociencias/

default prod.shtm_MAPAS $>$. Acesso em: $20 \mathrm{de}$ dez. 2013.

INSTITUTO AGRONÔMICO DE PERNAMBUCO - IPA. Recomendações de adubação para o estado de Pernambuco: $2^{\mathrm{a}}$ aproximação. 3 . ed. Recife, PE: IPA, 2008. 212 p.

JONES, R. M.; HARGREAVES, J. N. G. Improvements to the dry-weight-rank method for measuring botanical composition. Grass and Forage Science, Oxford, v. 34, n. 34, p. 181-189, 1979.

LAZARIDES, M, COWLEY, K.; HOHNEN, P. CSIRO Handbook of Australian Weeds. 1. ed. Collingwood, Victoria: CSIRO Publishing, 1997. $264 \mathrm{p}$.

LIMA, R. P. et al. Aporte e decomposição da serapilheira na Caatinga no Sul do Piauí. Revista Floresta e Ambiente, Rio de Janeiro, v. 22, n. 1, p. 42-49, 2015.

LITTELL, R. C.; HENRY, P. R.; AMMERMAN, C. B. Statistical analysis of repeated measures data using SAS procedures. Journal of Animal Science, v. 76, n. 4 , p. 1216-1231, 1998.

LOPES, J. F. B. et al. Deposição e decomposição de serapilheira em área da Caatinga. Revista Agroambiente, Boa Vista, v. 3, n. 2, p. 72-79, 2009.

LU, X. et al. Short-term grazing exclusion has no impact on soil properties and nutrients of degraded 
alpine grassland in Tibet, China. Solid Earth, Hoboken, v. 6, n. 4, p. 1195, 2015.

MARINHO, F. P. et al. Effects of past and present land use on vegetation cover and regeneration in a tropical dryland forest. Journal of Arid Environments, Londres, v. 132, n. 9, p. 26-33, 2016.

MCSHERRY, M. E., RITCHIE, M. E. Effects of grazing on grassland soil carbon: a global review. Global Change Biology, Oxford, v. 19, n. 5, p. 1347 $-1357,2013$.

MELO, R. O. et al. Susceptibilidade àcompactação e correlação entre as propriedades físicas de um Neossolo sob vegetação de Caatinga. Revista Caatinga, Mossoró, v. 21, n. 5, p. 12-17, 2008.

MILES, L.et al. A global overview of the conservation status of tropical dry forests. Journal of Biogeography, Oxford, v. 33, n. 3, p. 491-505, 2006.

MOREIRA, J. N. et al. Caracterização da vegetação e da dieta de ovinos em área de caatinga no sertão de Pernambuco. Pesquisa Agropecuária Brasileira, Brasília, v. 41, n. 11, p. 1643-1651, 2006.

MOURA, J. G. Caatinga manejada com diferentes ofertas de forragem e adubação fosfatada em diferentes épocas do ano, em Serra Talhada-PE. 2017. 108 f. Tese (Doutorado em Zootecnia: Área de concentração em Forragicultura) - Universidade Federal Rural de Pernambuco, Recife, 2017.

OLIVEIRA, O. F. et al. Características quantitativas e qualitativas de Caatinga raleada sob pastejo de ovinos, Serra Talhada (PE). Revista Caatinga, Mossoró, v. 28, n. 3, p. 223-229, 2015a.

OLIVEIRA, L. B. et al. Long-Term Effects of Phosphorus on Dynamics of an Overseeded Natural Grassland in Brazil. Rangeland Ecology \& Management, Lawrence, v. 68, n. 6, p. 445-452, $2015 b$

PEREIRA, I. M. et al. Regeneração natural em um remanescente de caatinga sob diferentes doses de perturbação, no agreste paraibano. Acta Botânica Brasílica, São Paulo, v. 15, n. 3, p. 431-426, 2001.

PEREIRA FILHO, J. M.; VIEIRA, E. L. Terminação de ovinos em pastagem: Uma Abordagem para o Semiárido. Semiárido em Foco, Campina Grande, v. 2, n. 1, p. 33-55, 2006

PREVEDELLO, C. L. Física do solo: com problemas resolvidos. 1. ed. Curitiba, PR: Salesward -Discovery, 1996. 446 p.
RIBEIRO, E. et al. Chronic anthropogenic disturbance drives the biological impoverishment of the Brazilian Caatinga vegetation. Journal of Applied Ecology, Oxford, v. 52, n. 3, p. 611-620, 2015.

SANTOS, M. V. F. et al. Potential of Caatinga forage plants in ruminant feeding. Revista Brasileira de Zootecnia, Viçosa, v. 39, suppl. spe. p. 204-215, 2010.

SILVA, M. C. et al. Avaliação de métodos para recuperação de pastagens de braquiária no agreste de Pernambuco. 1. Aspectos quantitativos. Revista Brasileira de Zootecnia, Viçosa, v. 33, n. 6, p. 1999 -2006, 2004.

SILVA, M. G. S. et al. Dinâmica da associação de capim-milhã e capim-de-raiz em pasto diferido. Revista Brasileira de Zootecnia, Viçosa, v. 40, n. 11 , p. 2340-2346, 2011

SILVA, T. G. F. et al. Soil water dynamics and evapotranspiration of forage cactus clones under rainfed conditions. Pesquisa Agropecuária Brasileira, Rio de Janeiro, v. 50, n. 7, p. 515-525, 2015.

SOARES, B. K. L. Influência do relevo nas características morfológicas e físicas de cambissolos no Semiárido pernambucano. 2015. 52 f. Monografia (Curso de Agronomia) Universidade Federal Rural de Pernambuco, Serra Talhada, 2015

MANNETJE, L. T.; HAYDOCK, K. P. The dryweight-rank method for the botanical analysis of pasture. Grass and Forage Science, Oxford, v. 18, n. 4, p. $268-75,1963$

TAWARAYA, K.; HIROSE, R.; WAGATSUMA, $\mathrm{T}$. Inoculation of arbuscular mycorrhizal fungi can substantially reduce phosphate fertilizer application to Allium fistulosum L. and achieve marketable yield under field condition. Biology and Fertility of Soils, Berlim, v. 18, n. 7, p. 839-843, 2012.

VANCE, C. P.; UHDE-STONE, C.; ALLAN, D. Phosphorus acquisition and use: critical adaptation by plants for securing non-renewable resources. New Phytologist, Cambridge, v. 157, n. 3, p. 423-447, 2003.

VELlOSO, A. L.; SAMPAIO, E. V. S. B.; PAREYN, F. G. C. Ecorregiões propostas para o bioma caatinga, 1. ed. Recife, PE: Associação Plantas do Nordeste, Instituto de Conservação Ambiental, The Nature Conservancy do Brasil, 2002. $76 \mathrm{p}$. 
WANG, D. et al. Grazing exclusion effects on above - and below-ground $\mathrm{C}$ and $\mathrm{N}$ pools of typical grassland on the Loess Plateau (China). Catena, Amsterdam, v. 123, n. 12, p. 113-120, 2014.

YDOYAGA-SANTANA, D. F. et al. Caracterização da caatinga e da dieta de novilhos fistulados, na época chuvosa, no semiárido de Pernambuco. Revista Brasileira de Zootecnia, Viçosa, v. 40, n. 1, p. 69-78, 2011.

YE, J. B. et al. Past climate change and recent anthropogenic activities affect genetic structure and population demography of the greater long-tailed hamster in Northern China. Integrative Zoology, Pequim, v. 10, n. 5, p. 482-496, 2015. 